\title{
Endometrial Lymphoma-Like Lesion
}

National Cancer Institute

\section{Source}

National Cancer Institute. Endometrial Lymphoma-Like Lesion. NCI Thesaurus. Code C126781.

Dense diffuse and superficial infiltration of the endometrium by lymphoid cells. It is typically seen in association with chronic endometritis. 